\title{
The history and natural regeneration of a secondary oak-beech woodland on a former wood-pasture in Hungary
}

\author{
Anna Varga*, Péter Ódor, Zsolt Molnár, János Bölöni \\ Centre for Ecological Research, Institute of Ecology and Botany, Hungarian Academy of Sciences, Klebelsberg Kuno u. 3, 8237 Tihany, Hungary
}

\begin{abstract}
Characteristic features of European woodland include both a reduction in natural forest areas and an increase in former agricultural areas occupied by secondary woodland. The management of these areas is challenging in terms of nature conservation, agricultural and forestry management and policy. The aim of our study was to reconstruct the history and to document the current tree stand structure for a secondary oak-beech woodland in Hungary. Towards the end of the 1800s, this area which was once almost completely occupied by a continuous forest, had been transformed into a wood-pasture. As a result of its gradual abandonment, the closed forest stand of the pasture increased from 10 to $52 \%$ between 1963 and 2005. The most characteristic feature of this woodland is the abundance of large trees. Globally, the number of large and ancient trees is rapidly diminishing. Therefore preserving and maintaining such areas, where large trees could live, is an essential management task.
\end{abstract}

Keywords: socio-economic changes; forest cover change; large trees; broadleaved forest; silvo-pastoral system

\section{Introduction}

The 20th-21st centuries have been witnessing a worldwide increase in areas occupied by secondary woodland [1-3] parallel to the continuous decline in natural old-growth forests spanning thousands of years. Socio-economic changes are the main drivers of secondary woodland development on former arable fields and pastures [4,5]. As an increasing proportion of contemporary forests is secondary in origin, their structure and composition are largely determined by past human influences, the recognition of which requires historical study of these forests [6]. This applies especially to temperate woodlands, because their type, character and state are determined by thousands of years of human activity, or indeed, neglect [7-9]. The extent and manner of their use are determined not only by environmental factors, but also by socio-economic factors $[10,11]$.

Since the industrial revolution, traditional land use has seriously declined in woodland regions of Europe [2,12]. A reduction in grazing intensity is one of the most significant changes in land use during the last 200 years [13-15]. Following World War II, abandonment of silvopastoral systems has accelerated throughout Europe [5,16]. In Central and Eastern Europe, a second stage of abandonment was generated by post-socialist processes $[11,17]$. After abandonment, both,

* Corresponding author. Email: varga.anna@gmail.com

Handling Editor: Zygmunt Kącki treeless areas and those with some form of woody vegetation spontaneously developed into closed forest [2,18-21]. Some of today's European secondary woodlands are the result of abandoning traditional forestry practices such as coppicing, whereas others have developed on post-agricultural land with or without woody vegetation [20].

A substantial area of post-agricultural land with woody vegetation is represented by abandoned wood-pastures and wood-meadows. Until the mid-20th century, these habitat types were a characteristic component of the pre-industrial European landscape $[1,12,22]$. Of the habitats traditionally used in silvopastoral systems, wood-pastures represent a transitional habitat between open grassland and closed forest, characterized by a mosaic-like pattern of open forest stands and scattered and often old trees [23,24]. Several studies have addressed the structure and history of Mediterranean and Alpine secondary woodlands that have developed from abandoned wood-pastures [2,25]. However, the information available on such stands in the Central and Eastern European part of the deciduous forest zone is scarce [26,27].

In Central and Eastern Europe, spontaneous secondary woodlands developed from abandoned agricultural land have become widespread in recent decades. This process has been shown to have important socio-economic and ecological implications. On the one hand, secondary woodlands that developed from wood-pastures and wooded meadows signify the decline of a special habitat maintained by humans, and the loss of traditional forms of land use and the associated knowledge [16]. On the other hand, the recently 
developed secondary woodlands may play an important role in the preservation of forest biodiversity, as follows: $(i)$ the diverse stand structure is important for the conservation of forest biodiversity [28]; (ii) where primeval, old-growth forest remains are scarce, as in the Central European mixed oak-beech woodland region [29], these forests are ideal sites for the study of natural forest dynamic processes; (iii) their study contributes to the knowledge of close to nature forestry [30,31].

It is particulary necessary for us to understand the history and former use of the land and the vegetation of abandoned wood-pastures if correct conservation and management decisions are to be made or further botanical research undertaken.

In this study, we present the detailed land use and vegetation history of Central and Eastern European abandoned, mixed oak-beech wood-pasture over the last 200 years. We also described the current tree stand structure, and examined the relationship between vegetation history and stand structure.

During our research we aimed to answer the following questions:

(i) How have the vegetation and use of a wood-pasture changed during the last 200 years?

(ii) What were the main driving forces for these changes over the last 200 years?

(iii) What are the characteristics of the tree stand structure of secondary woodland and abandoned wood-pasture and how do they vary with age?

\section{Material and methods}

\section{Study site}

The study area was the abandoned communal woodpasture of Olaszfalu village $\left(47^{\circ} 13^{\prime} 44.30^{\prime \prime} \mathrm{N}, 17^{\circ} 56^{\prime} 22.25^{\prime \prime} \mathrm{E}\right)$ in the Bakony hills, in the Transdanubian Mountains of Hungary. The abandoned wood-pasture is 255 ha in size, ranging in elevation from 380 to $480 \mathrm{~m}$. It is characterized by a hilly topography with gentle slopes, and with a moderately wet continental climate (mean annual temperature $9^{\circ} \mathrm{C}$, mean annual precipitation $700 \mathrm{~mm}$ ) [32]. The soils are rendzina and clayey brown forest soils, developed over limestone. In some parts of the study area, limestone and dolomite outcrops occur. The natural vegetation was mesic deciduous forest dominated by beech (Fagus sylvatica L.), sessile oak [Quercus petraea (Mattuschka) Lieblein.] and hornbeam (Carpinus betulus L.). The current vegetation of the abandoned wood-pasture is composed of a mixture of oak-hornbeam-beech woodlands, dry shrub vegetation (dominated by Crataegus monogyna Jacq., Prunus spinosa L.) and dry grasslands [the dominant species being Festuca rupicola Heuff., Stipa spp. and Chrysopogon gryllus (L.) Trin.] [33].

\section{Land use and vegetation historical reconstruction}

We selected this abandoned wood-pasture for our study because of the wealth of historical data available for this site and the absence of any significant forestry or other management interventions following the abandonment of pasturing. For the documentation of vegetation history, several useful written sources were available to us [unpublished archive sources = UAS; UAS/6: VeML. IV. 2. Fasc. 5. 112/1787, 1787. "Veszprém Vármegye II. József kori közigazgatási iratai” (Documents of Veszprém county from 1787)]. The most detailed of these sources, dating from the 19th century, was the 1818 forest survey and management plan. At this time, the area was owned by the Cistercian abbey at Zirc [UAS/7: VeML. XI. 601/b, 1818. "Erdőmesteri iratok" (Forestry documents from 1818)]. The registers and documents of the Olaszfalu commune refer to the state and use of pasturing from the end of the 19th century until the mid-20th century [UAS/5: VeML. 384, 1889. "Olaszfalu község képv”. T. jkv. 1. jkv. 1-1889 II. 23; VeML. XXI. 103, UAS/8: 1891-1950. “Olaszfalui volt úrbéres telkes gazdák erdőilletőségü erdejének rendszeres gazdasági terve” (UAS/8: "Plan of the forest of Olaszfalu village"); VeML. XXIV. 220, UAS/9: 1950. “Zirci Járási állami Gazdaság felügyelö” (Economics reports of the region of Zirc) 1950: 651-675]. The management of the Olaszfalu forest-common was organized by the local community [UAS/10: VeML. XXX. 1943-1963. “Olaszfalui erdőbirtokosság 1943-1963 iratai” (Documents of Olaszfalu forest-common)]. Apart from these, we also used the agricultural statistical data collection [34] and the village monograph of the closest neighboring commune [35].

The hand-drawn maps dating from 1781 [UAS/4: T 113. VeML. L133. 1781. "Mappa terreni possessionis. Olaszfalu". (Map of Olaszfalu)] and 1880 [UAS/2: T 78. VeML. L133. 1880. Kiss, A. "Olaszfalu helység mappája” (Map of Olaszfalu)] schematically represent the neighboring commune and its surrounding environs. The map, which is related to the 1818 forest survey, depicts the environmental and vegetation characteristics of the area, with an accuracy far in advance of its time [UAS/1: T 58. VeML. L133. 1818. Zmaly, F. "Forscarte des Olasfaluer Reviers" (Forest map of Olaszfalu)]. The 1862 hand-drawn map depicts the separation of the pasture and forest [UAS/3: T 84/2. VeML. L133. 1862. Müller, J.G. "Olaszfalu határának térképe” (Map of Olaszfalu)]. Further graphical sources include the military surveys of the Habsburg Empire: survey I. 1783-1784 (1: 28 800) [36]; survey II. 1848-1854 (1:28 800) [37]; and survey III. 1880 (1:10 000) [38].

During the collection of oral history and other local data, we conducted semi-structured interviews with 13 locals born between 1929 and 1952. Each interview lasted approximately 120 minutes. We conducted field surveys with two former herders, during which we identified landscape elements related to former land use. We also used 15 archive photographs of the area, taken between 1960-1970.

We analyzed black-and-white aerial photographs dating from 1963 and 1984 and a color aerial photograph from 2005. Based on these aerial photographs, we constructed historical habitat maps using the following four characteristic categories: woodland (canopy closure 60-100\%); parkland (canopy closure 10-60\%); shrubland (stands dominated by shrubs, canopy closure $<10 \%$ ) and grassland (grassy areas without woody species or with a cover of $<1 \%$ ). Geo-referencing of historical maps and aerial photos was performed using ArcGIS, and further processing was undertaken using QGIS.2.0.1. 


\section{The analysis of woody vegetation in the canopy-, shrub- and herb layer}

Tree measurements, vegetation survey

Recent woodlands were classified into four historical categories based on earlier aerial photographs (A-D in the Fig. 1). Within each category, seven stands were selected at haphazardly for stand structural analysis. The stand structure and tree species composition of the selected stands were documented in 2008 and 2009.

The canopy layer was sampled with $25 \times 25$ m quadrats. We recorded both, species identity and diameter at breast height $(\mathrm{DBH})$ of each woody plant that fell within the quadrat and in which DBH was $>1.5 \mathrm{~cm}$ at $1.3 \mathrm{~m}$ above ground, The shrub and herb layers were sampled by using $10 \times 10 \mathrm{~m}$ quadrats positioned at the center of the $25 \times 25 \mathrm{~m}$ quadrat. In woody plants found in the shrub layer, we recorded both, species identity and number of individuals. We considered woody plants with a $\mathrm{DBH}$ less than $1.5 \mathrm{~cm}$ and height greater than $0.5 \mathrm{~m}$ as part of the shrub layer. Woody plants shorter than $0.5 \mathrm{~m}$ were considered part of the herb layer. Values were standardized per hectare in the case of tree and shrub stem numbers.

\section{Data analysis}

Habitat history categories were compared by tree stand structure variables. In each case, we presented statistical information (average, dispersion), described the variables studied and tested their distribution for normality. We also tested if stand history had a significant effect on the studied variables by using analysis of variance (ANOVA). For those variables that did not fulfill the requirements for analysis of variance, we used the nonparametric Kruskal-Wallis H-test. We analyzed the distribution of each group relative to variables using the Tukey-HSD posthoc test for normally distributed variables, and the Kruskal-Wallis multiple comparison test for variables that were not normally distributed [39]. The statistical analysis was undertaken by using the PAST-statistics software [40].

\section{Results}

\section{Land use and vegetation history}

The studied area has been used by humans for millennia. During the Roman period, a road passed by the site. The area also includes the remains of a church dating presumably from the Middle Ages [41].

From the end of the 18 th century until the mid-19th century

During the 18 th century, $68 \%$ of the study area was covered with a 60 to 120 year-old forest. Half of the forest was dominated by beech, and the other half by oak. Areas of open, mixed grassland-shrubland were found only on stony, shallow soils, unsuitable for forestry use (32\%; UAS/7; Fig. 2). The study area was once owned and administered by the Cistercian abbey at Zirc. The map of the 1818 forestry plan suggests that the forest had already been managed according to the German system by then. Trees were used mainly for firewood, and local residents were allowed at times to use the forest for grazing (description of Veszprém county from 1720 in [41]; UAS/6; Tab. 1).

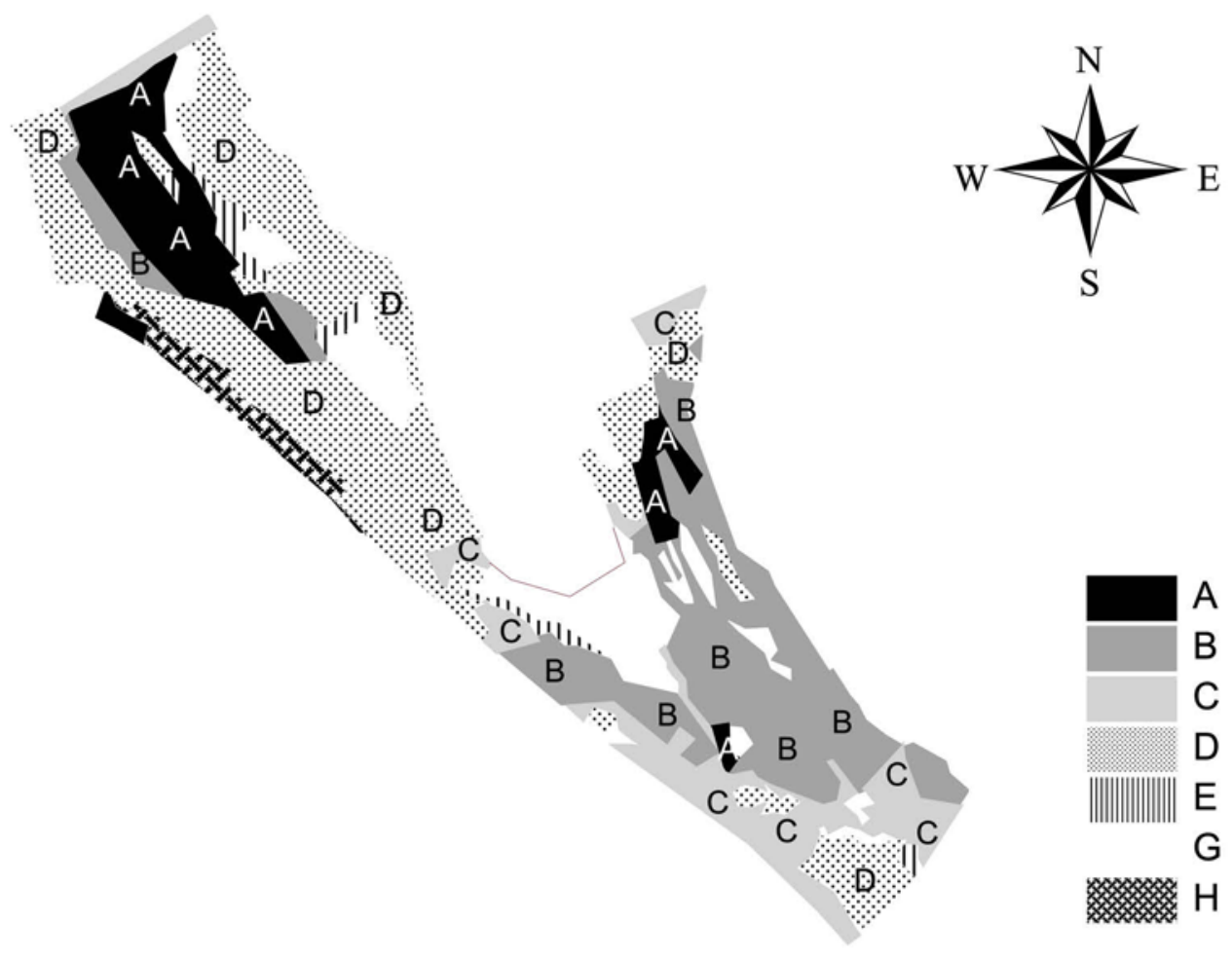

Fig. 1 Vegetation transformations of the study area (locations of the 28 sample quadrats are also shown). A - closed forest in 1818 until 2005; B - closed forest in 1818, parkland between 1880 and 1984; C - closed forest in 1818, parkland between 1880 and 2005; D - closed forest in 1818, parkland from 1880, parkland with shrub encroachment in 2005; E - open parkland in 1818 and 2005; G - grassland with shrubs in 1818 until 2005; H - closed forest in 1880, parkland between 1963 and 1984, arable field in 2005. 


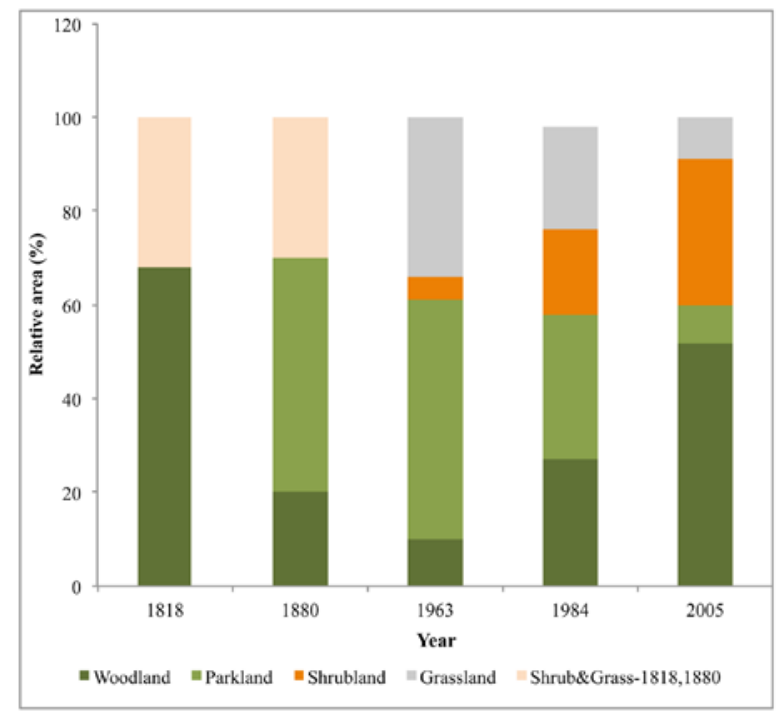

Fig. 2 The proportion of different habitat types in 1818, 1963, 1984 and 2005 in the studied mixed oak-beech woodland near Olaszfalu village (Hungary).

\section{From the mid-19th century until the mid-20th century}

Owing to the 1853 "Separation of forest and pasture" national law, the study area was separated legally and in practice from the forests of the Zirc abbey in 1862 (Tab. 1), and the ownership of the area was transferred to the local farmers at Olaszfalu. From this time on, the area was used as a communal pig and cattle pasture [38]. The development of a parkland habitat type dates back to the period of 1850-1880. At the end of the 19th century, most of the area was already parkland habitat, with only about $20 \%$ continuous forest (Third military survey [38]).

The use of the pasture was regulated by the grazing association of the local farmers at Olaszfalu. The area was grazed from the beginning of May until the end of October. The northern part of the area was used for grazing Mangalitza hogs (about 12.5 hogs/ha on average). Cattle had to cross the northern region and grazed in the southern part (about 1.5 cattle/ha on average). More recently, sheep were grazed on the site during the 1960-80s ([35]; personal communication by locals, 2009; Fig. 3).

The regular use of the area also included management of the canopy, shrub and herb layers of the vegetation. Most of these interventions were carried out during pasture cleaning in early spring, but shepherds also cleared the pasture from saplings and weeds that hampered grazing throughout the entire year. During pasture cleaning, locals also decided which saplings should be kept and allowed to grow. In order to protect the selected saplings, shrubs surrounding them were maintained or, in the absence of shrubs, thorny bushes were placed around the saplings (personal communication by locals, 2009). When the grass became too dry, or the amount of accumulated litter was too great, the quality of the grass was improved by pasture burning, mainly in early spring or autumn. Trees growing on the pasture were haphazardly pollarded, and the removed branches and twigs were used as firewood or as leaf forage, mainly during droughts. Decayed trees and those affected by disease were eventually felled and the wood sold.

By the beginning of the 20th century, the area was characterized by a parkland structure with seed-trees scattered throughout the pasture, as a result of this complex and deliberate management. The forest was composed of the following tree species: Carpinus betulus L., Fagus sylvatica L., Fraxinus excelsior L., Tilia platyphyllos Scop., Ulmus minor Mill., Prunus avium L., Pyrus pyraster (L.) Burgsd. and Malus sylvestris (L.) Mill (Pasture survey, 1945; personal communication by locals, 2009). The height of the tree trunks below the point of branching was 2-3 m. In 1945, the trees on the pasture were estimated to be $40-50$ years old. Of the shrub species, Prunus spinosa, Rosa spp. and Crataegus monogyna were scattered throughout the pasture area, and formed a belt at the boundary between pasture and arable field (UAS/9, 1950; personal communication by locals, 2009).

Tab. 1 The scales of socio-economic drivers influencing the changes of the mixed oak-beech woodland near Olaszfalu village (Hungary).

\begin{tabular}{|c|c|c|c|c|c|}
\hline \multirow[b]{2}{*}{ Scale } & \multirow[b]{2}{*}{$\begin{array}{l}\text { Driving forces, } \\
\text { pressures, actors }\end{array}$} & \multicolumn{4}{|c|}{ Time period } \\
\hline & & $1700-1862$ & 1862-1959 & 1959-2005 & $\begin{array}{l}\text { Beginning } \\
\text { of the } 21 \text { st } \\
\text { century onwards }\end{array}$ \\
\hline Global & Economic needs & Need for timber & & $\begin{array}{l}\text { The transformation of } \\
\text { agroforestry into large } \\
\text { scale production }\end{array}$ & \\
\hline National & Law, economic processes & $\begin{array}{l}\text { Separation of forest and } \\
\text { pasture }\end{array}$ & & & \\
\hline Regional & $\begin{array}{l}\text { The organization } \\
\text { controlling the use of } \\
\text { the area }\end{array}$ & The forester of the abbey & $\begin{array}{l}\text { Community of local } \\
\text { landowners }\end{array}$ & Soviet collective farm & $\begin{array}{l}\text { County office of the } \\
\text { National Forestry Agency }\end{array}$ \\
\hline \multirow[t]{4}{*}{ Local } & Owner & The abbey & $\begin{array}{l}\text { Community of local } \\
\text { landowners }\end{array}$ & Soviet collective farm & Private owners \\
\hline & $\begin{array}{l}\text { People working on } \\
\text { the land }\end{array}$ & Foresters, herders & $\begin{array}{l}\text { Herders, local } \\
\text { landowners }\end{array}$ & Herders, local people & Hunters, private owners \\
\hline & Primary use & Timber & Grazing & Grazing-decreasing & None \\
\hline & Secondary use & $\begin{array}{l}\text { Grazing and other non- } \\
\text { forest use }\end{array}$ & $\begin{array}{l}\text { Pollarding and other } \\
\text { non-forest use }\end{array}$ & Other non-forest use & $\begin{array}{l}\text { Hunting, personal wood } \\
\text { chopping }\end{array}$ \\
\hline
\end{tabular}




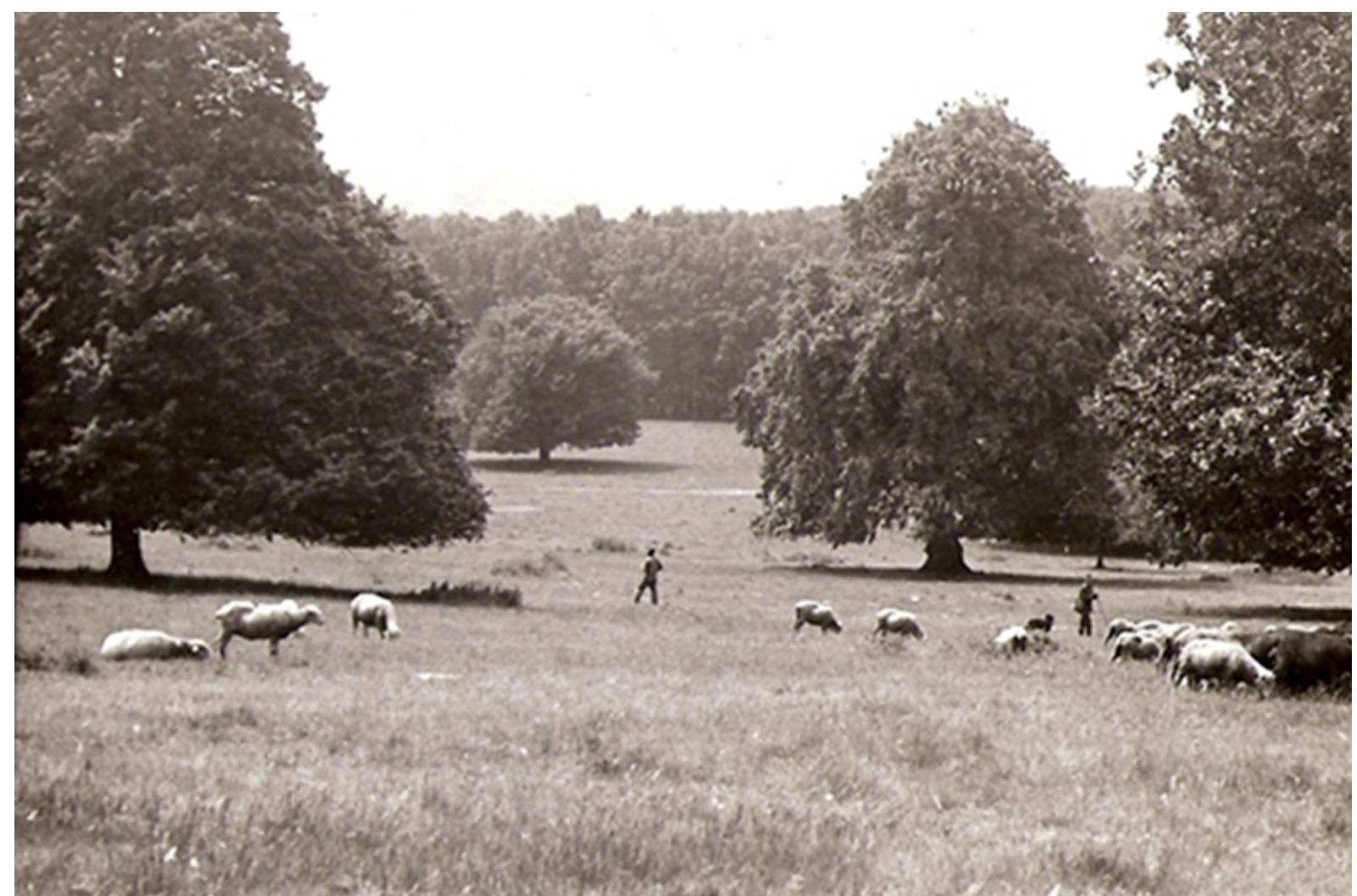

Fig. 3 Wood-pasture of Olaszfalu grazed by sheep in the 1960s. Photo by Ferenc Sándor.

From the mid-20th century until present

The collective farm was established at Olaszfalu in 1959. Following this, regular pasture cleaning practices and deliberate vegetation management were abandoned (personal communication by locals, 2009). The 1963 aerial photograph shows the area to have had a parkland, open wood-pasture character (51\%), but encroachment by shrubs had already begun and was by now visible (5\%; Fig. 1, Fig. 3). Following collectivization, the number of grazing animals decreased drastically. The gradual abandonment of grazing continued until 2003 (personal communication by locals, 2009). By the 1980s, because of abandonment, intensive shrub encroachment and the development of secondary woodland were noticeable in the former parkland. Between 1963 and 1984, the open wood-pasture-like areas of the parkland declined by $19 \%$, whereas the open grassland areas declined by $12 \%$ (Fig. 3).

In 1999, one part of the study area was subject to a forestry management plan, but no interventions were undertaken [42]. The local hunting society placed out several hunting platforms and feeders following the abandonment of grazing, and still performs regular shrub management on the access roads.

Based on the 2005 aerial photograph, 52\% of the study area was covered by woodland. This compares with $76 \%$ woodland areas for 1818 (Fig. 4). According to the 2005 aerial photograph, open grassland can now be found almost exclusively on those areas that were once open due to local habitat conditions, rocky soils and rocky outcrops (Fig. 4).

In 2008, the area was divided into parcels and allocated to private owners. In 2009, private owners started to thin some of the parcels invaded by shrubs and secondary woodland, and began planting non-native tree species (Robinia pseudoacacia L., Juglans nigra L.).

\section{Driving forces during the last 200 years}

Driving forces at various levels determined changes in land use and vegetation in the area. Globally, from the beginning of the 19th century until present, land use patterns were governed by the energy and food industries. One feature of this period was the application of methodology developed by the German forestry school, as demonstrated by the operations maps and stand descriptions of the area dating from 1818. Global demand is mainly demonstrated by legislation at the national level. Land use in the area was most affected by the "Forest and pasture separation act of 1853 " and the Soviet collectivization of the 1950s. Regionally, these impacted on the identity and role of the owner, decision maker and land user. Whereas back in the mid-19th century land users had been partly owners and decision makers for the area, by the middle of the 20th century, only usage rights were retained, owing to the collectivization process. With privatization, land use rights and ownership became divided, whereas, since the area was afforested, decision-making now came under the authority of the state forest service.

All of these trends had an impact on local processes by affecting decision-making at the regional level and thus determining the rights and responsibilities of people working locally. This has had a profound influence on the intensity and patterns of land use that could be practiced in the area, as well as the personal ambitions and motivations of the people working there. 


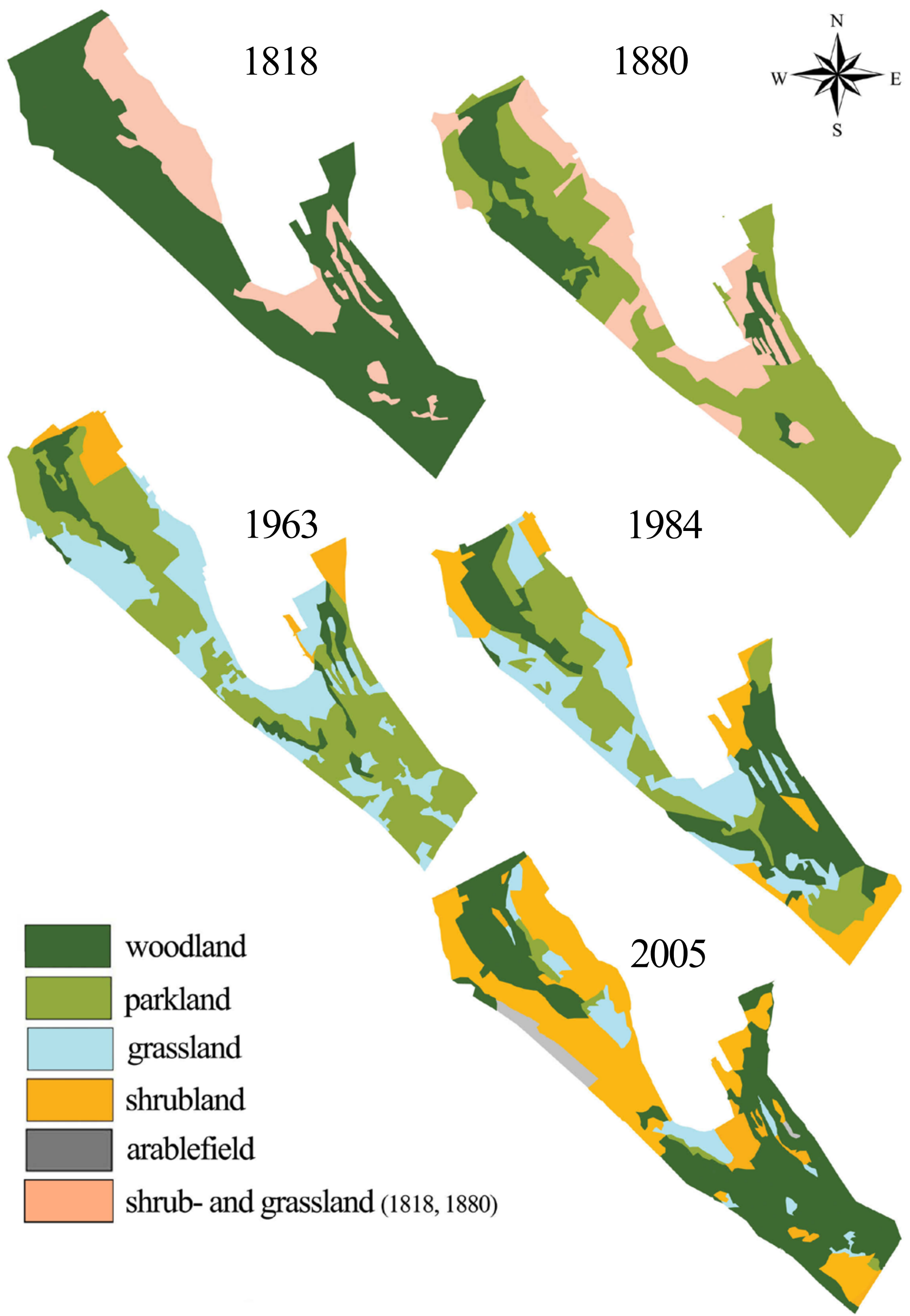

Fig. 4 Vegetation and land-use categories of the study area near Olaszfalu village (Hungary) in 1818, 1880, 1963, 1984 and 2005. 


\section{Forest structure and composition}

\section{Diameter distribution}

The distribution of trunk diameter in the four historical forest categories covered a wide range from the minimum of $1.3 \mathrm{~cm}$ to more than $100 \mathrm{~cm}$ in categories $\mathrm{A}$ and $\mathrm{C}$. The distribution curve approximately resembled a reversed letter "J" (Fig. 5) in each forest category. In comparing The diameter distribution of the four historical categories revealed differences in the process of secondary woodland development in areas containing relatively large trees. In stands where this process began many years ago, tree density diminished in a more or less linear manner relative to increasing size category. The size distribution of trees developed after abandonment and of the original trees of the former wood-pasture were not greatly different.

In areas abandoned post-1963, the two historical categories differed sharply. The later the development of the secondary woodland, the more pronounced the difference. Trees that developed following abandonment were found in the $<25 \mathrm{~cm}$ size category. Trees of the former wood-pasture were distributed relatively evenly across size categories $>25$ $\mathrm{cm}$, whereas the effect of self-thinning was not evident. Early abandonment resulted in larger trees, with the result that size distribution was greater than in the case of more recently abandoned groups.
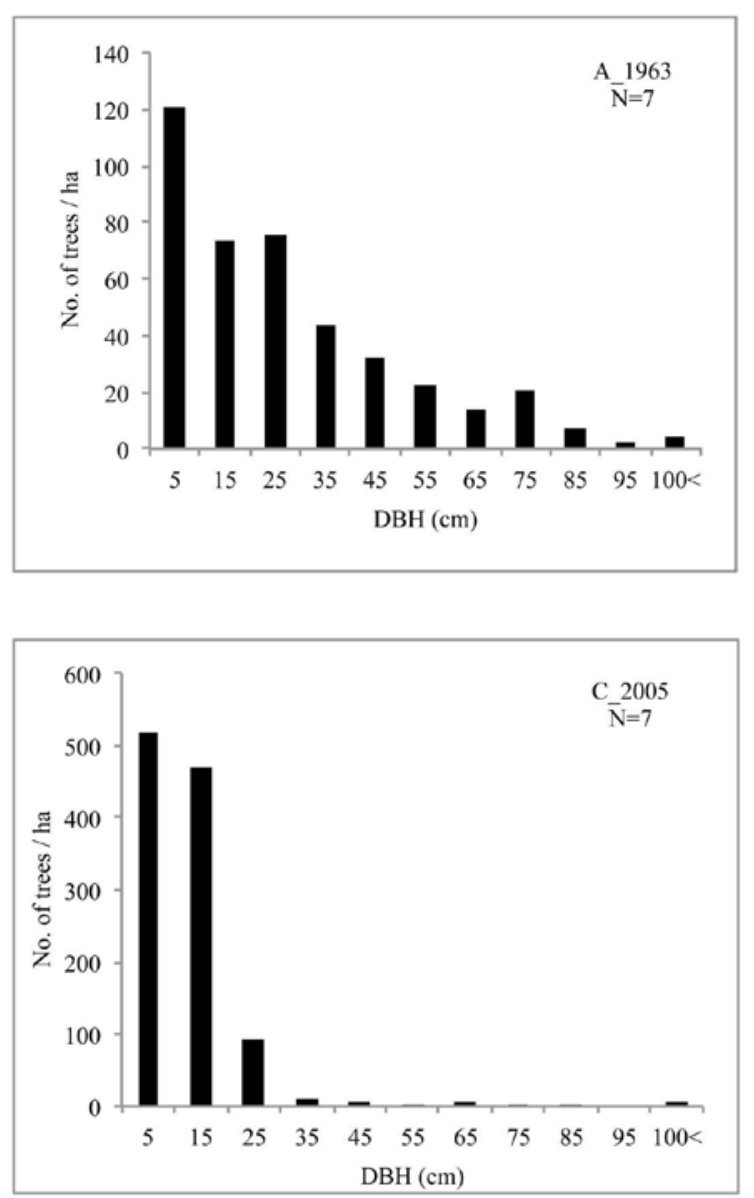

Composition and structure

The studied variables demonstrate that the forest stand was diverse and had a multi-layered structure (Tab. 2). The average tree cover of the forest stands was $68 \%$.

Total density, the density of DBH levels and the average number of species found in forest stands differing in age were significantly different. Forest types A (forest with closed canopy pre-1963), and D (open wood-pasture affected by shrub encroachment) had the lowest total density.

The historical forest category (A), which had a closed canopy before 1963, was characterized by a high basal area. Forest categories of $\mathrm{B}$ and $\mathrm{C}$ had the highest densities and the greatest number of species. Shrub density was the greatest in category D (the open wood-pasture affected by shrub encroachment). However, this value did not differ significantly from the values in categories B and C.

\section{Large tree analysis}

The density of large trees was $17 \pm 22.8$ trees/ha in the entire area. Most large trees were found in the closed oldgrowth forest, whereas the fewest ones occurred in the open wood-pasture, which was affected by shrub encroachment. Trees with the largest basal areas were found in the B type stands, the canopy of which closed during 1963-1984. Of the large trees, 35\% was Fagus sylvatica, 15\% was Acer campestre, and $14 \%$ was Quercus cerris (Tab. 3). The highest number of
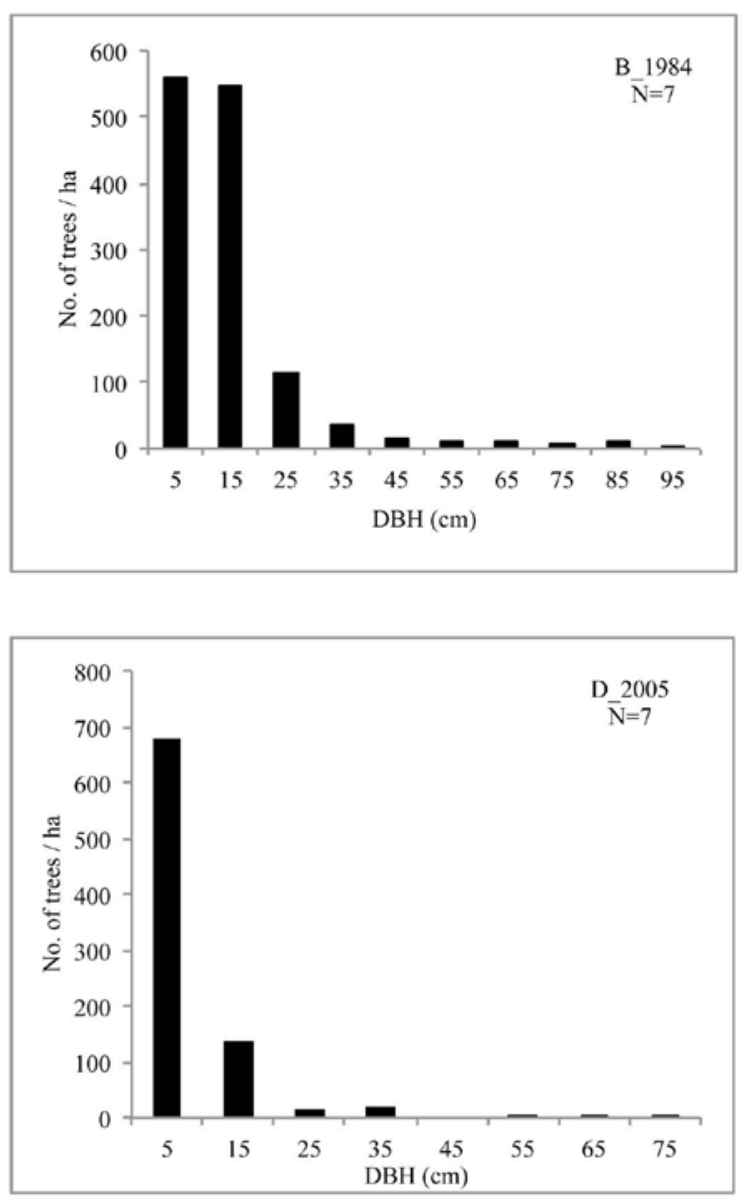

Fig. 5 Mean diameter distribution of the four stand types and the entire studied mixed oak-beech woodland near Olaszfalu village (Hungary). A_1963 - closed woodland of the wood-pasture in 1963; B_1984 - stands afforested between 1963 and 1984; C_2005 - stands afforested between 1984 and 2005; D_2005 - parkland under afforestation in 2005. 
species for large trees was in stand B, while in stand D, only one species was found (Acer campestre).

\section{Discussion}

\section{Changing woodland use}

The key driver of change during the last 200 years has been industrialization $[1,10,43]$. Since the end of the 18 th century, the German forest management type centered on timber production has become increasingly widespread in response to increasing demand for energy [43,44]. In Hungary, this management type was introduced very early even from a European perspective, especially on the estates owned by landlords and the church. The 1818 forest survey provides evidence of this. Not only was the German system pre-eminent in Hungary, but it also dominated forest management throughout Europe $[5,43]$. The German forestry school promoted production-based, single focus forestry as opposed to the multifunctional usage that characterized the preceding period $[4,44]$. As a consequence, traditional forest management gradually waned leading to the reduction of extensive animal husbandry and forest grazing. It is evident that this process eventually precipitated the separation of pasturing and forestry [24,27]. The law for this separation came into force in Hungary in 1853, and applied to those areas within the landlord's forest that were allocated to local farmers for grazing. At the same time, free grazing rights in the forests owned by landlords were abolished, which completely transformed traditional silvopastoral systems [45]. In our study area, there is no information as to the size of forests that were grazed prior to separation of forests and pastures. However, based on data from northern Hungary (Felsőtárkány), it seems that the amount of forest pasture allocated to a village community decreased by up to $15 \%$ following implementation of this law [46]. Forest parcels for grazing were transformed into distinct wood-pastures.
In these pastures, the traditional forest grazing practiced until that time was adapted and applied to the reduced area. These changes had already occurred in different parts of Northern Europe during the 18th century or even earlier. Like in Hungary, this resulted in modification of land-use, changes in ownership, regulation of land use and also the people who managed that land $[7,18,43,47]$.

Globally, the use of wood-pastures entails the conscious management of the tree stand with the aim of developing and maintaining an open structure $[19,22,48,49]$. As in other deciduous wooded pastures, more than half of our study area was characterized by an open wood-pasture structure during the first half of the 20th century [50]. Wood-pasture management included grassland maintenance, facilitation of tree regeneration, maintenance of seed-trees, and coppicing and felling of dead and rotting trees, or those that hampered grazing [51]. Management practices also included burning. The importance and role of fire in wood-pasture and grassland management in Central and East Europe has only recently been recognized [52,53]. This type of nonforest use is closely related to traditional land-use based on traditional ecological knowledge [16,54]. Evidence for

Tab. 3 Species composition (\%) of large trees $(70 \mathrm{~cm}<\mathrm{DBH})$ in the A-D forest habitat types.

\begin{tabular}{lrrrc}
\hline & A & B & C & D \\
\hline Fagus sylvatica & 68 & 0 & 22 & 0 \\
Sorbus torminalis & 6 & 0 & 0 & 0 \\
Carpinus betulus & 0 & 33 & 0 & 0 \\
Quercus cerris & 0 & 24 & 56 & 0 \\
Quercus petrea & 6 & 0 & 0 & 0 \\
Tilia cordata & 21 & 10 & 0 & 0 \\
Cerasium avium & 0 & 24 & 0 & 0 \\
Acer campestre & 0 & 10 & 22 & 100 \\
\hline
\end{tabular}

Tab. 2 The average and distribution of variables describing the tree stand structure of the mixed oak-beech woodland (Olaszfalu, Hungary).

\begin{tabular}{|c|c|c|c|c|c|c|c|c|c|}
\hline & Variables & Mean & $\mathbf{A}$ & B & $\mathrm{C}$ & $\mathbf{D}$ & $F$ & $\boldsymbol{H}$ & $P$ \\
\hline $\mathrm{A} / \mathrm{D}$ & Cover of the canopy layer & $68 \pm 5$ & $92 \pm 2 \mathrm{a}$ & $88 \pm 4 a$ & $82 \pm 4 a$ & $53 \pm 7 b$ & 10.1 & & 0.001 \\
\hline $\mathrm{A} / \mathrm{D}$ & Total diameter & $15 \pm 16$ & $27 \pm 23 a$ & $14 \pm 13 b$ & $13 \pm 12 b$ & $9 \pm 9 b$ & & & 0.004 \\
\hline $\mathrm{TN}$ & Total density (stem/ha) & $308 \pm 361$ & $416 \pm 152 a$ & $1317 \pm 497 \mathrm{~b}$ & $1117 \pm 415 b$ & $861 \pm 559 a$ & & & 0.008 \\
\hline $\mathrm{A} / \mathrm{D}$ & Total number of species & 20 & 10 & 15 & 17 & 11 & & & \\
\hline $\mathrm{A} / \mathrm{D}$ & Average number of species & $6 \pm 2.1$ & $4.5 \pm 1.2 \mathrm{a}$ & $7.1 \pm 1.2 \mathrm{~b}$ & $8 \pm 1.4 b$ & $4.2 \pm 2.1 \mathrm{a}$ & & 15.6 & 0.001 \\
\hline $\mathrm{A} / \mathrm{D}$ & Total basal area $\left(\mathrm{m}^{2} / \mathrm{ha}\right)$ & $0.5 \pm 1.6$ & $1.6 \pm 2.5 \mathrm{a}$ & $0.5 \pm 1.2 \mathrm{~b}$ & $0.4 \pm 1.9 \mathrm{~b}$ & $0.2 \pm 0.8 b$ & 9.86 & & 0.001 \\
\hline $\mathrm{A} / \mathrm{D}$ & Shrub stem number (stem/ha) & $4180 \pm 3423$ & $595 \pm 866 a$ & $1190 \pm 1284 a$ & $6148 \pm 6238 a$ & $8785 \pm 4031 b$ & 5.428 & & 0.007 \\
\hline $\mathrm{A} / \mathrm{D}$ & Shrub species number & $4.8 \pm 3.9$ & $2 \pm 1.8$ & $3.25 \pm 2.48$ & $5.2 \pm 4.2$ & $8.75 \pm 0.9$ & & & 0.063 \\
\hline $\mathrm{A} / \mathrm{D}$ & Regeneration stem number (stem/ha) & $7254 \pm 5219$ & $5571 \pm 1976$ & $8544 \pm 7185$ & $6767 \pm 4360$ & $8133 \pm 5377$ & & & 0.985 \\
\hline $\mathrm{A} / \mathrm{D}$ & Regeneration species number & $6.6 \pm 1.9$ & $7 \pm 0.7$ & $5.5 \pm 2.6$ & $7.25 \pm 1$ & $6.8 \pm 2.1$ & & & 0.579 \\
\hline $\mathrm{A} / \mathrm{D}$ & Large tree density (stem/ha) & $17.7 \pm 22.8$ & $343 \pm 35.1$ & $20.6 \pm 11.9$ & $9.1 \pm 7.9$ & $6.8 \pm 11.6$ & 2.373 & & 0.095 \\
\hline $\mathrm{A} / \mathrm{D}$ & Large tree species number & $3.3 \pm 1.7$ & $1.14 \pm 0.9 \mathrm{a}$ & $13 \pm 0.7 \mathrm{a}$ & $0.6 \pm 0.5 \mathrm{a}$ & $0.3 \pm 0.5 b$ & & 6.141 & 0.067 \\
\hline $\mathrm{A} / \mathrm{D}$ & Large tree basal area $\left(\mathrm{m}^{2} / \mathrm{ha}\right)$ & $41.2 \pm 40.4$ & $60.3 \pm 38.7 \mathrm{a}, \mathrm{b}$ & $72.7 \pm 30.7 b$ & $9.8 \pm 12.4 c$ & $21.9 \pm 34.7 \mathrm{a}, \mathrm{c}$ & 5.719 & & 0.004 \\
\hline
\end{tabular}

A - closed woodland before 1963; B - 1963-1984 secondary woodland in open wood-pasture; C - secondary woodland developed in open wood-pasture between 1984-2005; D - open wood-pasture, with secondary woodland development in 2005. Level of significance: $P>0.05$. $F$ - parametric, ANOVA one-way analysis of variance (ANOVA); $H$ - non-paramteric, Kruskal-Wallis one-way analysis of variance by ranks. The small letters "a", "b", "c" show the most coherent groups. A/D - average/distribution; TN - total number. 
conscious tree management of silvopastoral systems comes from the observation that the scattered seed-trees were all the same age, and thus dated from the time that the area was transformed into a pasture [55]. This is consistent with another study [47] that investigated the age distribution of dehesa trees in the Iberian Peninsula.

The abandonment of traditional land use also was accelerated by the production of food at an industrial scale, as well as the need to increase fuel-wood energy production [1]. These processes had started in some parts of Northern Europe prior to World War II $[43,56]$. As a result, closed forest areas have been increasing and traditional ecological knowledge has been declining in Western Europe up to the present $[1,16,57]$. In Eastern Europe, these changes became evident a little later commencing in the 1950-60s, after the establishment of the Soviet agricultural system [11,58], which is supported by our findings. During collectivization, land ownership was taken away from local communities in tandem with the liquidation of other commons [7,54]. As a consequence, these communities lost interest in the longterm maintenance of land, including the termination of the deliberate management of open wood-pastures. In the study area, the portion occupied by closed forest increased by $40 \%$ in 40 years because of this process. A similar scenario was suggested for a German site characterized by mixed oak-beech wood-pasture that was abandoned in the 1960s. Here, the proportion of the closed forest area increased by $50 \%$ [50]. Forest stands developed on post-agricultural areas were taken over by natural dynamic processes in response to cessation of management, depending on national legislation and the timing of forestry planning [16]. The threshold for an abandoned agricultural area to be classified as forest differs from country to country. In Hungary, it is 30\% canopy cover. Beyond this threshold, the use of the area is regulated by forestry law [59]. In recent decades, the management of European woodland areas has been increasingly influenced by other drivers such as nature conservation, recreational use and hunting, as is the case at our study site. These drivers often change the existing pattern of land use [10].

\section{The main characteristics of the stand structure}

Tree diameter distribution for the entire woodland stand studied and that of individual stand types resembled a flattened, reversed letter J. The end of the distribution curve was more even compared with that of the classic reversed J shape characteristic of old-growth owing to the high proportion of large trees present. The bell-shaped distribution curve characteristic of wood-pastures was not observed for any of the stand types studied [45].

In the study area, the most important indicators of former wood-pasture use were the large basal area $\left(41.2 \mathrm{~m}^{2} / \mathrm{ha}\right)$ and high proportion of mainly pollarded, large trees (17 \pm 22.8 trees/ha), which also is typical of other former wood-pastures [47,60]. In Europe and North America, 10-20 large living trees per hectare can be found in a deciduous old-growth forest, while 0-9 large living trees/ha can be found in managed forest stands [61-63]. Conversely, large living trees are almost entirely absent from old-growth and managed high forest stands in Hungary [29]. Based on this information, we conclude that the large living tree value for the studied woodland is high, both at the regional and European level. The species composition of large trees corresponded well with the 1945 pasture survey and the recollections of local people. The three dominant species were Fagus sylvatica, Acer campestre and Quercus cerris. Compared to other wood-pastures, large Pyrus pyraster trees were absent from our study site (see e.g. [27]). All Pyrus pyraster trees present were smaller than $70 \mathrm{~cm}$ DBH. This is surprising, because this species traditionally played an important role for autumn feeding of livestock and for production of spirit and dried fruit in the study area, as in other parts of Europe ([51,64] and personal communication by locals, 2009).

The average number of woody species for the studied area was $6 \pm 2.1 / \mathrm{ha}$, similar to deciduous woodlands that have been managed as forest reserves within the region [41]. The diverse structure and composition of the studied woodland stands indicate that no forestry management interventions have occurred during the last decade. Instead, they reflect other characteristic former land-uses, including woodland management $[3,63]$. Compared with the findings reported here, abandonment of former agricultural areas that lacked woody species prior to the cessation of management practices usually results in the development of dense, homogeneous secondary woodland stands characterized by uniform age structure and a low number of woody species [65-67]. Following the abandonment of a wood-pasture, however, a natural, secondary woodland developed that is characterized by diverse stand structure $[68,69]$.

\section{Conclusion and further management}

The land use of the study area was determined by global processes, national policies, local landscape characteristics, and a complex system of interacting factors operating at a variety of levels. Following the transformation of non-forest management and the transformation of the silvopastoral system, the forest stands have changed significantly during the last 200 years. The tree stand structure of the spontaneously developed secondary woodland was simultaneously determined by former land use, the history of the abandonment and local habitat conditions. When discussing the future management of spontaneous secondary woodland development on post-agricultural sites, several aspects should be taken into consideration. While setting up a management strategy, local habitat conditions, former land-use practices, present and future ecological values and economic objectives should all be considered. In certain cases, secondary woodlands similar to those at our study site can form a valuable forest habitat. However, the rapid disappearance of active wood pastures of high-nature value draws the attention to the need of their reconstruction and maintenance. Wood-pastures are key habitats for large and veteran trees [27], and are sources of both, species and landscape diversity. Reconstruction methods of abandoned wood pastures are site specific. Tree regeneration, ancient tree conservation, sustainable livestock type and density are the key elements of a wood-pasture reconstruction management plan. Based on our land-use historical study and other field experiences, systematic and well-planned management of woody species 
is at the core of the conservation and maintenance of a woodpasture. This also is emphasized by one of the most complete wood-pasture management and conservation guides from

\section{Acknowledgments}

We are grateful for the collaboration and help of knowledgeable elders and local people from Olaszfalu, especially Németh Antal, Némethné Hajas Marika, Hajas Lajos, Dobos Imréné, Tölgyesi Alberik and Szaturi György. We acknowledge the help of the Balaton Uplands National Park Directorate and the Veszprém County Archives. We also gratefully acknowledge the language review of Kinga Öllerer and Dr. Kevin L. Davies. We greatly appreciate the insightful comments and helpful edits of the anonymous reviewers.

This work was supported by the TÁMOP 4.2.4. A/2-11-1-2012-0001 "National Excellence Program - elaborating and operating an inland student and researcher personal support system convergence program" and partly supported by "Sustainable conservation on Hungarian Natura 2000 sites (SH/4/8)" within the framework of the Swiss contribution program.

\section{Authors' contributions}

The following declarations about authors' contributions to the research have been made: field work: AV; writing the manuscript: AV, ZM, JB, PÓ.

\section{Competing interests}

No competing interests have been declared.

\section{References}

1. Agnoletti M. The degradation of traditional landscape in a mountain area of Tuscany during the 19th and 20th centuries: implications for biodiversity and sustainable management. For Ecol Manage. 2007;249:5-17. http://dx.doi.org/10.1016/j.foreco.2007.05.032

2. Chételat J, Kalbermatten M, Lannas KSM, Spiegelberger T, Wettstein JB, Gillet F, et al. A contextual analysis of land-use and vegetation changes in two wooded pastures in the Swiss Jura Mountains. Ecol Soc. 2013;18:39. http://dx.doi.org/10.5751/es-05287-180139

3. Holz S, Placci G, Quintana RD. Effects of history of use on secondary forest regeneration in the Upper Parana Atlantic Forest (Misiones, Argentina). For Ecol Manage. 2009;258: 1629-1642. http://dx.doi. org/10.1016/j.foreco.2009.07.023

4. Bürgi M, Schuler A. Driving forces of forest management - an analysis of regeneration practices in the forests of the Swiss Central Plateau during the 19th and 20th century. For Ecol Manage. 2003;176:173-183. http://dx.doi.org/10.1016/s0378-1127(02)00270-0

5. Bomanowska A, Kiedrzyński M. Changing land use in recent decades and its impact on plant cover in agricultural and forest landscapes in Poland. Folia Biologica et Oecologica. 2011;7:5-26. http://dx.doi. org/10.2478/v10107-009-0014-1

6. Foster D, Swanson F, Aber J, Burke I, Brokaw N, Tilman D, et al. The importance of land-use legacies to ecology and conservation. BioScience. 2003;53:77-88. http://dx.doi.org/10.1641/0006-3568(2003)053[0077:ti olul] 2.0.co; 2

7. Rackham O. Ancient woodland, its history, vegetation and uses in England. London: Edward Arnold; 1980.

8. Bengtsson J, Nilsson SG, Franc A, Menozzi P. Biodiversity, disturbances, ecosystem function and management of European forests. For Ecol Manage. 2000;132:39-50. http://dx.doi.org/10.1016/ s0378-1127(00)00378-9

9. Dambrine E, Duopoey JL, Laut L, Humbert L, Thinon M, Beaufils T, et al. Present forest biodiversity patterns in France related to former Roman agriculture. Ecology. 2007;88:1430-1439. http://dx.doi. org/10.1890/05-1314

10. Szabó P. Driving forces of stability and change in woodland structure: a case-study from the Czech lowlands. For Ecol Manage. 2010;259:650656. http://dx.doi.org/10.1016/j.foreco.2009.11.026

11. Lieskovský J, Kenderessy P, Špulerová J, Lieskovský T, Koleda P, Kienast F, et al. Factors affecting the persistence of traditional
UK [70]. Even though the number of reconstruction projects is increasing in Central and Eastern Europe, region-specific guidelines and best practices are still lacking.

agricultural landscapes in Slovakia during the collectivization of agriculture. Landsc Ecol. 2014;29:867-877. http://dx.doi.org/10.1007/ s10980-014-0023-1

12. Sammul M, Kattai K, Lanno K, Meltsov V, Otsus M, Nõuakas L, et al. Wooded meadows of Estonia: conservation efforts for a traditional habitat. Agric Food Sci. 2008;17:413-429. http://dx.doi. org/10.2137/145960608787235513

13. Motta R, Edouard JL. Stand structure and dynamics in a mixed and multilayered forest in the Upper Susa Valley, Piedmont, Italy. Can J For Res. 2005;35:21-36. http://dx.doi.org/10.1139/x04-153

14. Piussi P, Farrell EP. Interactions between society and forest ecosystems: challenges for the near future. For Ecol Manage. 2000;132:21-28. http://dx.doi.org/10.1016/s0378-1127(00)00376-5

15. Isselstein J, Jeangros B, Pavlů V. Agronomic aspects of biodiversity targeted management of temperate grasslands in Europe - a review. Agron Res. 2005;3:139-151.

16. Johann E, Agnoletti M, Bölöni J, Erol SC, Holl K, Kusmin J, et al. Europe. In: Parrotta JA, Trosper RL, editors. Traditional forest-related knowledge: sustaining communities, ecosystems and biocultural diversity. New York, NY: Springer; 2012. p. 203-249. (World forests; vol 12).

17. Kuemmerle T, Hostert P, Radeloff VC, van der Linden S, Perzanowski K, Kruhlov I. Cross-border comparison of postsocialist farmland abandonment in the Carpathians. Ecosystems. 2008;11:614-628. http://dx.doi.org/10.1007/s10021-008-9146-Z

18. Muster S, Elsenbeer H, Conedera M. Small-scale effects of historical land use and topography on post-cultural tree species composition in an Alpine valley in southern Switzerland. Landsc Ecol. 2007;22:1187-1199. http://dx.doi.org/10.1007/s10980-007-9099-1

19. Vera WM. Grazing ecology and forest history. Wallingford: CABI; 2000. http://dx.doi.org/10.1079/9780851994420.0000

20. Hédl R, Kopecky M, Komárek J. Half a century of succession in a temperate oakwood: from species-rich community to mesic forest. Divers Distrib. 2010;16:267-276. http://dx.doi. org/10.1111/j.1472-4642.2010.00637.x

21. Kwiatkowska AJ, Wyszomirski T. Decline of Potentillo albae-Quercetum phytocoenoses associated with the invasion of Carpinus betulus. Vegetatio. 1988;75:49-55. http://dx.doi.org/10.1007/bf00042948

22. Rackham O. Savanna in Europe. In: Kirby JK, Watkins C, editors. The ecological history of European forests. Oxon: CAB; 1998. p. 1-24.

23. Bergmeier E, Petermann J, Schröder E. Geobotanical survey of wood-pasture habitats in Europe: diversity, threats and conservation. Biodivers Conserv. 2010;19:2995-3014. http://dx.doi.org/10.1007/ s10531-010-9872-3

24. Bölöni J, Molnár Z, Biró M, Horváth F. Distribution of the (semi-) natural habitats in Hungary II. Woodlands and shrublands. Acta Bot Hung. 2008;50:107-148. http://dx.doi.org/10.1556/abot.50.2008. suppl.6

25. Rozas V. Regeneration patterns, dendroecology, and forest-use history in an old-growth beech-oak lowland forest in Northern Spain. For Ecol Manage. 2003;182:175-194. http://dx.doi.org/10.1016/ s0378-1127(03)00070-7

26. Szabó P, Hédl R. Socio-economic demands, ecological conditions and the power of tradition: past woodland management decisions in a Central European landscape. Landsc Res. 2013;38:243-261. http:// dx.doi.org/10.1080/01426397.2012.677022

27. Hartel T, Dorresteijn I, Klein C, Máthé O, Moga CI, Öllerer K, et al. Wood-pastures in a traditional rural region of Eastern Europe: characteristics, management and status. Biol Conserv. 2013;166:267-275. http://dx.doi.org/10.1016/j.biocon.2013.06.020

28. Brunet J, Fritz Ö, Richnau G. Biodiversity in European beech forests 
- a review with recommendations for sustainable forest management. Ecological Bulletins. 2010;53:77-94.

29. Horváth F, Bidló A, Heil B, Király G, Kovács G, Mányoki G, et al. Abandonment status and long-term monitoring of strict forest reserves in the Pannonian biogeographical region. Plant Biosyst. 2012;146:189-200. http://dx.doi.org/10.1080/11263504.2011.650728

30. Bürgi M, Gimmi U. Three objectives of historical ecology: the case of litter collecting in Central European forests. Landsc Ecol. 2007;22:7787. http://dx.doi.org/10.1007/s10980-007-9128-0

31. Szabó P, Hédl R. Advancing the integration of history and ecology for conservation. Conserv Biol. 2011;25:680-687. http://dx.doi. $\operatorname{org} / 10.1111 / \mathrm{j} .1523-1739.2011 .01710 . \mathrm{x}$

32. Merusch I, Práger T, Ambrózy P, Hunkár M, Dunkel Z, editors. Magyarország éghajlati atlasza. Budapest: Országos Meteorológiai Szolgálat; 2002.

33. Sonnevend I. Olaszfalu és Eplény határának növény- és állatvilága. In: Hudi I, editor. Olaszfalu: Olaszfalu története; 2005

34. MSA. Mezőgazdasági Statisztikai Adatgyűjtemény. Állattenyésztés III. Községsoros adatok. Budapest: KSH; 1972.

35. Hudi J. Olaszfalu története. Olaszfalu: Olaszfalu Község Önkormányzata; 2005.

36. The first military survey [DVD]. Budapest: Arcanum; 2004.

37. The second military survey [DVD]. Budapest: Arcanum; 2005

38. The third military survey [DVD]. Budapest: Arcanum; 2007.

39. Reiczigel J, Harnos A, Solymosi N. Biostatisztika. Nem statisztikusoknak. Nagykovácsi: Pars Kft; 2007.

40. Hammer O. PAST: PAleontological STatistics. Version 2.17. Oslo: Natural History Museum, University of Oslo; 2012.

41. Boross I, Madarász L. Veszprém vármegye összeírása 1696, 1715, 1720. Veszprém: Veszprém Megyei Levéltár; 2002. (A Veszprém Megyei Levéltár Kiadványai; vol 17).

42. ÁESZ. Üzemterv. Állami Erdészeti Szolgálat; 1999.

43. Bürgi M. A case study of forest change in the Swiss lowlands. Landsc Ecol. 1999;14:567-575. http://dx.doi.org/10.1023/A:1008168209725

44. Linares A. Forest planning and traditional knowledge in collective woodlands of Spain: the dehesa system. For Ecol Manage. 2007;249:71-79. http://dx.doi.org/10.1016/j.foreco.2007.03.059

45. Varga A, Bölöni J. Erdei legeltetés, fáslegelők, legelőerdők tájtörténeti kutatása. Természetvédelmi Közlemények. 2009;15:68-79.

46. Petercsák T, editor. Az erdő szerepe Felsőtárkány életében. In: Az életmód változása egy bükki faluban. Budapest: Eger; 1986. p. 128-136. (Néprajzi Tanulmányok Heves megyében; vol 4).

47. Plieninger T, Pulido FJ, Konold W. Effects of land-use history on size structure of holm oak stands in Spanish dehesas: implications for conservation and restoration. Environ Conserv. 2003;30:61-70. http://dx.doi.org/10.1017/s0376892903000055

48. Hartel T, Pilinger T, editors. European wood-pastures in transition. A social-ecological approach. London: Routledge; 2014.

49. Manning AD, Fisher J, Lindenmayer DB. Scattered trees are keystone structures: implications for conservation. Biol Conserv. 2006;132:311321. http://dx.doi.org/10.1016/j.biocon.2006.04.023

50. Ginzler O, Simmering D, Waldhardt R, Otte A. Vegetation dynamics of a wood-pasture landscape in the Lahn-Dill-Highlands (Hesse, Germany). In: Otte A, Simmering D, Eckstein L, Hölzel N, Waldhardt $\mathrm{R}$, editors. Eco-complexity and dynamics of the cultural landscape: abstracts of the talks and posters presented at the 34th annual conference of the Ecological Society in Giessen, September 13th-17th, 2004; Berlin: Ecological Society in Giessen; 2004. p. 382. (Proceedings of the GfÖ; vol 34)

51. Varga A, Molnár Z. The role of traditional ecological knowledge in managing wood-pastures. In: Hartel T, Plininger T, editors. European wood-pastures in transition. Earthscan. London: Routledge; 2014. p. 187-202.
52. Deák B, Valkó O, Török P, Végvári Z, Hartel T, Schmotzer A, et al. Grassland fires in Hungary - experiences of nature conservationists on the effects of fire on biodiversity. Appl Ecol Environ Res. 2014;12:267-283. http://dx.doi.org/10.15666/aeer/1201_267283

53. Öllerer K. The ground vegetation management of wood-pastures in Romania - insights in the past for conservation management in the future. Appl Ecol Environ Res. 2014;12:549-562. http://dx.doi. org/10.15666/aeer/1202_549562

54. Andrásfalvy B. A Duna mente népének ártéri gazdálkodása. Szekszárd: Ekvilibrium; 2007

55. Saláta D, Szabó M, Kenéz Á, Malatinszky Á, Demény K, Breuer L. Adatok a Pénzesgyőr-Hárskúti hagyásfás legelö tájtörténetéhez. Tájökológiai Lapok. 2007;5:19-25.

56. Piovesan G, Di Filippo A, Alessandrini A, Biondi F, Schirone B Structure, dynamics and dendroecology of an old-growth Fagus forest in the Apennines. J Veg Sci. 2005;16:13-28. http://dx.doi. org/10.1111/j.1654-1103.2005.tb02334.x

57. Rotherham ID. The implications of perceptions and cultural knowledge loss for the management of wooded landscapes: a UK case-study. For Ecol Manage. 2007;249:100-115. http://dx.doi.org/10.1016/j. foreco.2007.05.030

58. Angelstam P, Elbakidze M, Axelsson R, Cupa R, Halada L, Molnar Z, et al. Maintaining cultural and natural biodiversity in the Carpathian Mountain ecoregion: need for an integrated landscape approach. In: Kozak J, Ostapowicz K, Bytnerowicz A, Wyżga B, editors. Integrating nature and society towards sustainability. Berlin: Springer. 2013. p. 393-424. http://dx.doi.org/10.1007/978-3-642-12725-0_28

59. 2009. évi XXXVII. törvény az erdőről, az erdő védelméről és az erdőgazdálkodásról (Hungarian Forestry Law).

60. Holl K, Smith M. Scottish upland forests: history lessons for the future. For Ecol Manage. 2007;249:45-53. http://dx.doi.org/10.1016/j. foreco.2007.04.042

61. Nilsson SG, Niklasson M, Hedin J, Aronsson G, Gutowski JM, Linder $\mathrm{P}$, et al. Densities of large and dead trees in old-growth temperate and boreal forests. For Ecol Manage. 2003;161:189-204. http://dx.doi. org/10.1016/s0378-1127(01)00480-7

62. von Oheimb G, Brunet J. Dalby Söderskog revisited: long-term vegetation changes in a south Swedish deciduous forest. Acta Oecol 2007;31:229-242. http://dx.doi.org/10.1016/j.actao.2006.12.001

63. Bilek L, Remes J, Zahradnik D. Managed vs. unmanaged. Structure of beech forest stands (Fagus sylvatica L.) after 50 years of development, Central Bohemia. For Syst. 2011;20:122-138. http://dx.doi. org/10.5424/fs/2011201-10243

64. Dénes A, Papp N, Babai D, Czúcz B, Molnár Z. Wild plants used for food by Hungarian ethnic groups living in the Carpathian Basin. Acta Soc Bot Pol. 2012;81:381-396. http://dx.doi.org/10.5586/asbp.2012.040

65. Alberti G, Peressotti P, Piussi P, Zerbi G. Structure and stand development of secondary forests in Eastern Prealps (Italy). Dendrochronologia. 2009;27:173-181. http://dx.doi.org/10.1016/j.dendro.2008.02.002

66. Mitka J, Jakubowska-Gabara J. Ancient woodland plant species in a landscape park in central Poland. Acta Soc Bot Pol. 2007;76:239-249. http://dx.doi.org/10.5586/asbp.2007.027

67. Hellberg E, Hörnberg G, Östlund L, Zackrisson O. Vegetation dynamics and disturbance history in three deciduous forests in boreal Sweden. J Veg Sci. 2003;14:267-276. http://dx.doi. org/10.1658/1100-9233(2003)014[0267:vdadhi]2.0.co;2

68. Bartha D, Ódor P, Horváth T, Tímár G, Kenderes K, Standovár T, et al. Relationship of tree stand heterogeneity and forest naturalness. Acta Silv Lignaria Hung. 2006;2:7-22.

69. Carvalho JPF. Composition and structure of natural mixed-oak stands in northern and central Portugal. For Ecol Manage. 2011;262:19281937. http://dx.doi.org/10.1016/j.foreco.2011.04.020

70. Holl K, Smiths M. Ancient wood-pasture in Scotland: classification and managment principels. Scottish Natural Heritage Commissioned Report FO 1AA108; 2002. 